\title{
Intestinal permeability in strongyloidiasis
}

A.L. Werneck-Silva ${ }^{1}$ A.M. Sipahi, A.O.M.C. Damião, C.A. Buchpiguel ${ }^{2}$, K. Iriya ${ }^{3}$ and A.A. Laudanna ${ }^{1}$

\author{
${ }^{1}$ Laboratório de Investigação M édica (LIM 07), \\ Departamento de Gastroenterologia, Hospital das Clínicas, and \\ Departamentos de ${ }^{2}$ Radiologia and ${ }^{3}$ Patologia, Faculdade de Medicina, \\ Universidade de São Paulo, São Paulo, SP, Brasil
}

\section{Correspondence \\ A.M. Sipahi \\ Rua Joaquim Floriano, $72 \mathrm{Cj} 72$ \\ 04534-000 São Paulo, SP \\ Brasil \\ Fax: +55-11-820-7457 \\ E-mail: aytan@usp.br}

Publication supported by FAPESP.

Received May 15, 2000

Accepted January 9, 2001

\section{Abstract}

The objective of the present study was to assess intestinal permeability in patients with infection caused by Strongyloides stercoralis. Twentysix patients ( 16 women and 10 men), mean age 45.9 , with a diagnosis of strongyloidiasis were evaluated. For comparison, 25 healthy volunteers (18 women and 7 men), mean age 44.9 , without digestive disorders or intestinal parasites served as normal controls. Intestinal permeability was measured on the basis of urinary radioactivity levels during the $24 \mathrm{~h}$ following oral administration of chromium-labeled ethylenediaminetetraacetic acid ( ${ }^{51} \mathrm{Cr}$-EDTA) expressed as percentage of the ingested dose. The urinary excretion of ${ }^{51} \mathrm{Cr}$-EDTA was significantly reduced in patients with strongyloidiasis compared to controls $(1.60 \pm 0.74$ and $3.10 \pm 1.40$, respectively, $\mathrm{P}=0.0001)$. Intestinal permeability is diminished in strongyloidiasis. Abnormalities in mucus secretion and intestinal motility and loss of macromolecules could explain the impaired intestinal permeability.

\section{Key words}

- Intestinal permeability

. ${ }^{51} \mathrm{Cr}$-EDTA

- Strongyloidiasis

- Small bowel

\section{Introduction}

The intestinal epithelium plays a major role in the digestion and absorption of fluids and nutrients and also represents an efficient barrier that protects the host from environmental pathogens and antigens (1). Impaired barrier function intensifies antigen access, which in turn leads to an exaggerated immune stimulation that initiates or perpetuates inflammation (2). Increased intestinal permeability has been described in inflammatory bowel disease (3-11), atopic eczema (12), celiac disease and dermatitis herpeti- formis (13), cystic fibrosis (14,15), alcohol consumption (16), use of nonsteroidal antiinflammatory drugs (17-20), and acute infectious diarrhea $(12,21)$. On the other hand, decreased intestinal permeability has been demonstrated in Blastocystis hominis infection (22).

Strongyloidiasis is a common parasitosis in tropical areas and is associated with a wide spectrum of clinical manifestations ranging from asymptomatic conditions to hyperinfection in immunocompromised patients (23-26). It colonizes the duodenum and upper jejunum, and usually affects the mucosal 
layer of the intestine, although the whole intestinal wall may be involved in severe cases (23-26). Also, our group has described small bowel overgrowth (27) which could explain in part the high frequency of Gramnegative sepsis associated with the severe cases with widespread dissemination of larvae (28). Intestinal permeability has not been evaluated in strongyloidiasis. Thus, in the present study, intestinal permeability was investigated by means of chromium-labeled ethylenediaminetetraacetic acid $\left({ }^{51} \mathrm{Cr}\right.$ EDTA) in patients infected with Strongyloides stercoralis.

\section{Material and Methods}

Twenty-six patients (16 women and 10 men) with strongyloidiasis were prospectively studied. Their ages ranged from 23 to 70 years $($ mean $=45.9)$. The diagnosis of strongyloidiasis was confirmed by identification of the worm in at least two stool examinations by the method of Rugai et al. (29) (three samples). For comparison, 25 asymptomatic healthy volunteers ( 18 women and 7 men) aged 24 to 68 years (mean = 44.9) without digestive disorders or intestinal parasites and with normal upper gastrointestinal endoscopy served as normal controls. Exclusion criteria included: a) other parasitoses detected by the methods of Faust (30) and Hoffmann et al. (31) (three samples); b) nonsteroidal anti-inflammatory drugs or alcohol consumption; c) acute or chronic renal insufficiency, diabetes mellitus and systemic arterial hypertension; d) celiac disease, inflammatory bowel disease or gastroenteritis; e) previous gastric or intestinal surgery. Our Hospital Ethics Committee approved the research protocol and informed consent was obtained from all subjects.

Blood samples were taken from patients and controls for laboratory data (blood count, glucose, urea/creatinine ratio, and sodium and potassium levels). Enteroscopy (Enteroscope SIF 10, Olympus) was performed in the patients with strongyloidiasis and four duodenal and four jejunal biopsies were taken. All specimens were examined by the same pathologist (K.I.). Inflammation was scored as mild, moderate and severe according to the classification of De Paola et al. (23). The control group was submitted to digestive endoscopy (GIF PQ 10, Olympus) to rule out inflamed or ulcerated lesions. Intestinal permeability was measured by the method described by Bjarnason et al. (32) using ${ }^{51} \mathrm{Cr}$-EDTA. Briefly, after an 8 -h period of fasting, the patients ingested a solution with $0.6 \mu \mathrm{mol}$ of ${ }^{51} \mathrm{Cr}$-EDTA containing about $100 \mu \mathrm{Ci}$ of radioactivity. The patients then drank $300 \mathrm{ml}$ of water and after $2 \mathrm{~h}$ were permitted to eat normally. A 24-h urine sample was then analyzed for radioactivity. Permeability data were expressed as percentage of excreted radioactivity in relation to the total administered dose.

Results are reported as means $\pm \mathrm{SD}$. The chi-square and Student $t$-tests were used to determine differences between the two groups. The probability value accepted as significant was $\mathrm{P}<0.05$.

\section{Results}

The two groups were similar regarding age, gender, distribution and all laboratory data, except for eosinophilia (>400 eosinophils $/ \mathrm{mm}^{3}$ ) which was detected in $56 \%$ of the patients. Most patients (92\%) were symptomatic. Symptoms included epigastric pain (69\%), diarrhea (62\%), weight loss (31\%) and nausea/vomiting (12\%). Enteroscopy was normal in $69 \%$ of the patients $(\mathrm{N}=18)$. Erosive gastritis was seen in one patient (4\%). Six patients had bulboduodenitis $(23 \%)$ and one bulboduodenitis and jejunitis (4\%). Larvae were detected in the duodenal aspirate from 6 patients $(23 \%)$ and were absent in the other $20(77 \%)$. Histologic evaluation was normal in 5 patients (19\%), whereas chronic duodenitis and jejunitis were observed in 21 patients (81\%) and scored as 
mild in 15 , moderate in 5 , and severe in 1. In these 21 patients, an increased number of goblet cells was observed. Villous atrophy was only detected in one case (severe). Strongyloides stercoralis larvae were identified histologically in 4 cases, with infestation scored as mild in 1, moderate in 2, and severe in 1 . Four patients presented larvae in both duodenal and histological material.

Figure 1 shows the intestinal permeability data for patients with strongyloidiasis and controls. The urinary excretion of ${ }^{51} \mathrm{Cr}$ EDTA was significantly reduced in patients with strongyloidiasis compared to controls $(1.60 \pm 0.74$ and $3.10 \pm 1.40$, respectively, $\mathrm{P}$ $=0.0001)$. Patients with histologically moderate or severe inflammation had lower values than those with mild inflammation (1.38 \pm 0.71 versus $1.54 \pm 0.75$ ) and normal histology $(2.08 \pm 1.68)$, but the difference was not significant $(\mathrm{P}=0.19)$.

\section{Discussion}

In the present investigation, we have studied intestinal permeability in patients infected with Strongyloides stercoralis (mild/ moderate disease), a nematode particularly found in tropical and subtropical areas. Urinary radioactivity levels during the $24 \mathrm{~h}$ following oral administration of ${ }^{51} \mathrm{Cr}$-EDTA, expressed as percentage of the ingested dose, were significantly reduced in patients with strongyloidiasis (Figure 1). Similarly, Zuckerman et al. (22) also demonstrated decreased intestinal permeability to ${ }^{51} \mathrm{Cr}$-EDTA in pa- tients infected with Blastocystis hominis. It is important to point out that our results for intestinal permeability to ${ }^{51} \mathrm{Cr}$-EDTA in healthy controls $(3.10 \pm 1.40)$ are higher than those obtained in England (1.90\%) (13), Canada (1.34\%) (8), Belgium (2.51\%) (12), Norway (2.45\%) (33) and Italy (2.25\%) (34). However, they are similar to the data from Israel (4.05\%) (35) and from another group in Brazil (3.14\%) (36). Methodological differences are probably not the reason for these differences since we used the same method for measuring intestinal permeability as used by these investigators. Differences in diet, socioeconomic and nutritional conditions, frequency of bacterial infections and parasitosis may account for these discrepant results $(8,34,37,38)$.

The mechanisms underlying intestinal permeability to molecular markers like EDTA in this parasitosis are still unknown. The following possible mechanisms have been suggested. First, the intestinal inflammatory response in strongyloidiasis is accompanied by enhanced mucus secretion (39). In fact, in our series, most of the patients showed an increased number of goblet cells on histology. The increase in the surface mucus layer in strongyloidiasis could render the intestinal barrier less permeable to EDTA. Also, the intestinal cell turnover is highly increased in strongyloidiasis (40) and could impair the paracellular route of intestinal permeability markers like EDTA. Second, most of our patients (62\%) had diarrhea. Accordingly, accelerated intestinal transit has frequently

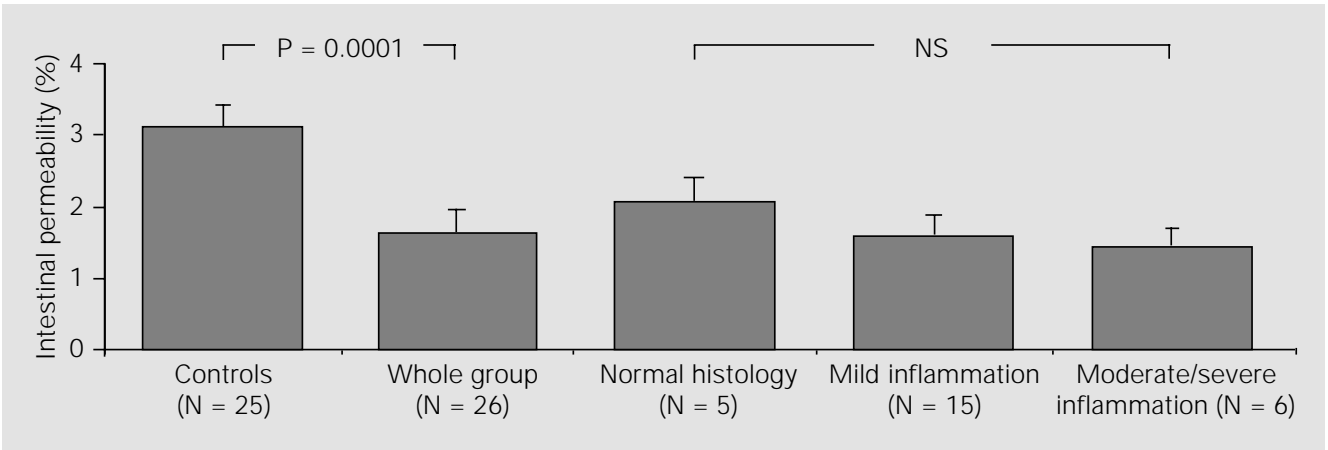

Figure 1 - Intestinal permeability in strongyloidiasis. Urinary excretion of ${ }^{51} \mathrm{Cr}$-EDTA is reported as percentage of total administered radioactivity (mean \pm SD) in patients with strongyloidiasis (whole group, normal histology, mild and moderate/severe chronic duodenitis and jejunitis). Intestinal permeability was significantly reduced in patients with strongyloidiasis; there was a negative correlation between intestinal permeability and inflammation but the values were not statistically significant. NS, Nonsignificant. 
been described in strongyloidiasis (41) and it is possible that the little time for contact between EDTA and the intestinal mucosa affected permeation by the marker. However, this assumption must be evaluated with caution in view of a recent report stating that small intestinal transit has no influence on the excretion of ${ }^{51} \mathrm{Cr}$-EDTA, at least in healthy individuals (42). Finally, proteinlosing enteropathy has been demonstrated in strongyloidiasis (43) and one may speculate that EDTA is lost by the same intestinal pathway as protein.

Whatever the mechanisms involved, our first description of diminished intestinal permeability in strongyloidiasis is relevant in view of the high prevalence of this parasitosis in some developing countries and its physiopathologic implications. Whether very severe cases of strongyloidiasis with multiple small bowel ulcers or hyperinfection will disclose the same intestinal permeability pattern we have seen in our patients with mild and moderate disease remains to be elucidated.

\section{Acknowledgments}

The authors gratefully acknowledge the expert editorial assistance of Maria Laura Lacava Lordello.

\section{References}

1. Kraehenbuhl J -P, Pringault E \& Neutra MR (1997). Intestinal epithelia and barrier functions. Alimentary Pharmacology and Therapeutics, 11 (Suppl 3): 3-9.

2. Sartor RB (1995). Current concepts of the etiology and pathogenesis of ulcerative colitis and Crohn's disease. Gastroenterology Clinics of North America, 3: 475507.

3. Ainsworth M, Eriksen J, Waever Rasmussen J \& Schaffalitzk de Muckadell OB (1989). Intestinal permeability of ${ }^{51} \mathrm{Cr}$-labelled ethylenediaminetetraacetic acid in patients with Crohn's disease and their healthy relatives. Scandinavian J ournal of Gastroenterology, 24: 993-998.

4. Bjarnason I, O'M orain C, Levi AJ \& Peters TJ (1983). Absorption of ${ }^{51}$ chromium-labeled ethylenediaminetetraacetate in inflammatory bowel disease. Gastroenterology, 85: 318-322.

5. Hollander $D$, Vadheim CM, Brettholz E, Petersen GM, Delahunty T\& Rotter J I (1986). Increased intestinal permeability in patients with Crohn's disease and their relatives. Annals of Internal Medicine, 105: 883-885.

6. Hollander D (1988). Crohn's disease - a permeability disorder of the tight junction? Gut, 29: 1621-1624.

7. Hollander D (1992). The intestinal permeability barrier: a hypothesis as to its regulation and involvement in Crohn's disease (Review). Scandinavian J ournal of Gastro- enterology, 27: 721-726.

8. J enkins $R T$, J ones $D B$, Goodacre RL, Collins SM, Coates G, Hunt RH \& Bienenstock JT (1987). The reversibility of increased intestinal permeability to ${ }^{51} \mathrm{Cr}$ EDTA in patients with gastrointestinal inflammatory diseases. American J ournal of Gastroenterology, 82: 1159-1164.

9. J enkins RT, Ramage J K, J ones DB, Collins SM, Goodacre RL \& Hunt RH (1988). Small bowel and colonic permeability to ${ }^{51} \mathrm{Cr}$-EDTA in patients with active inflammatory bowel disease. Clinical and Investigative Medicine, 11: 151-155.

10. O'Morain CA, Abelow AC, Chervu LR, Fleischner GM \& Das KM (1986). Chromium ${ }^{51}$-ethylenediaminetetraacetate test: a useful test in the assessment of inflammatory bowel disease. J ournal of Laboratory and Clinical Medicine, 108: 430-435.

11. Zuckerman MJ \& Watts MT (1993). Intestinal permeability to ${ }^{51} \mathrm{Cr}$-ethylenediaminetetraacetate in patients with ulcerative colitis. American J ournal of Gastroenterology, 88: 1978-1979.

12. Forget $P$, Sodoyez-Goffaux $F \&$ Zappitelli A (1985). Permeability of small intestine to $\left.{ }^{51} \mathrm{Cr}\right]$ EDTA in children with acute gastroenteritis or eczema. J ournal of Pediatric Gastroenterology and Nutrition, 4: 393396.

13. Bjarnason I, Marsh MN, Price A, Levi AJ \& Peters TJ (1985). Intestinal permeability in patients with coelic disease and derma- titis herpetiformis. Gut, 26: 1214-1219.

14. Escobar H, Perdomo M, Vasconez F, Camarero C, Del Olmo MT \& Suárez L (1992). Intestinal permeability to ${ }^{51} \mathrm{Cr}$ EDTA and orocecal transit time in cystic fibrosis. J ournal of Pediatric Gastroenterology and Nutrition, 14: 204-207.

15. Leclerq-Foucart J, Forget $P$, SodoyezGoffaux F \& Zappitelli A (1986). Intestinal permeability to $\left.{ }^{51} \mathrm{Cr}\right]-\mathrm{EDTA}$ in children with cystic fibrosis. Joumal of Pediatric Gastroenterology and Nutrition, 5: 384387.

16. Bjarnason I, Wark K \& Peters TJ (1984). The leaky gut of alcoholism: possible route of entry for toxic compounds. Lancet, 1: 179-182.

17. Aabakken $L \&$ Osnes M (1990). ${ }^{51}$ Cr-ethylenediaminetetraacetic acid absorption test. Effects of naproxen, a non-steroidal, anti-inflammatory drug. Scandinavian J ournal of Gastroenterology, 25: 917-924.

18. Bjarnason I, So A, Levi AJ, Peters TJ, Williams P, Zanelli GD, Gumpel J M \& Ansell B (1984). Intestinal permeability and inflammation in rheumatoid arthritis: effects of non-steroidal anti-inflammatory drugs. Lancet, 2: 1171-1173.

19. Bjarnason I, Williams $P$, Smerthurst $P, P e-$ ters TJ \& Levi AJ (1986). Effect of nonsteroidal anti-inflammatory drugs and prostaglandins on the permeability of the human small intestine. Gut, 27: 12921297. 
20. J enkins AP, Trew DR, Crump BJ , Nukajam WS, Foley J A, Menzies IS \& Creamer B (1991). Do non-steroidal anti-inflammatory drugs increase colonic permeability? Gut, 32: 66-69.

21. Zuckerman MJ, Watts MT, Bhatt BD \& Ho H (1993). Intestinal permeability to $\left.{ }^{[1} \mathrm{Cr}\right]$ EDTA in infectious diarrhea. Digestive Diseases and Sciences, 38: 16511657.

22. Zuckerman MJ, Watts $M T$, Ho $H$ \& Meriano FV (1994). Blastocystis hominis infection and intestinal injury. American J ournal of the Medical Sciences, 308: 96101.

23. De Paola D, Braga-Dias L \& Silva JR (1962). Enteritis due to Strongyloides stercoralis. American J ournal of Digestive Diseases, 7: 1086-1098.

24. Britt DP, Khan HA \& Florentino AO (1989). Strongyloides infection in an immunosuppressed patient. Medical Principles and Practice, 1: 63-64.

25. Cook GC (1987). Strongyloides stercoralis hyperinfection syndrome: how often is it missed? Quarterly J ournal of Medicine, 244: 625-629.

26. Purtilo DT, Meyers WM \& Connor DH (1974). Fatal strongyloidiasis in immunosuppressed patients. American J ournal of Medicine, 56: 488-493.

27. Sipahi AM, Damião AOMC, Simionato CS, Bonini N, Santos MAA, Moraes-Filho J PP, Laudanna AA \& Betarello A (1991). Small bowel bacterial overgrowth in strongyloidiasis. Digestion, 49: 120-124.

28. Igra-Siegman $Y$, Kapila R, Sen P, Kaminski Z\& Louria DB (1981). Syndrome of hyper- infection with Strongyloides stercoralis. Reviews of Infectious Diseases, 3: 397407.

29. Rugai E, Mattos T \& Brisola AP (1954). Nova técnica para isolar larvas de nematóides das fezes. Modificação do método de Baermann. Memórias do Instituto Adolfo Lutz, 14: 5-8.

30. Faust EC (1939). Human Helminthology. 2nd edn. Lea \& Febiger, Philadelphia.

31. Hoffmann WA, Pons JA \& J aner J L (1934). The sedimentation-concentration method in Schistosomiasis mansoni. Puerto Rico J ournal of Health and Tropical Medicine, 9: 283-294.

32. Bjarnason I, Peters TJ \& Veall N (1983). A persistent defect in intestinal permeability in coeliac disease demonstrated by ${ }^{51}$ Cr-labelled EDTA absorption test. Lancet, 1: 323-325.

33. Aabakken L (1989). ${ }^{51}$ Cr-ethylenediaminetetraacetic acid absorption test. Methodologic aspects. Scandinavian J ournal of Gastroenterology, 24: 351-358.

34. Pironi $L$, Miglioni $M$, Ruggeri $E$, Levorato M, Dallasta MA, Corbelli C, Nibaldi MG \& Barbara L (1991). Relation between intestinal permeability to $\left.{ }^{51} \mathrm{Cr}\right]$ EDTA and inflammatory activity in asymptomatic patients with Crohn's disease. Digestive Diseases and Sciences, 35: 582-588.

35. Peled Y, Watz C \& Gilat T (1985). Measurement of intestinal permeability using ${ }^{51}$ Cr-EDTA. American J oumal of Gastroenterology, 80: 770-773.

36. Troncon LEA, Pires CR, Kraus OA \& lazigi $N$ (1996). Estudo da permeabilidade intestinal pelo teste do ${ }^{51} \mathrm{Cr}$-EDTA. Arquivos de Gastroenterologia, 33: 66-73.

37. Ukabam SO, Homeida MMA \& Cooper BT (1986). Small intestinal permeability in normal Sudanese subjects: evidence of tropical enteropathy. Transactions of the Royal Society of Tropical Medicine and Hygiene, 80: 204-207.

38. Menzies IS, Zuckerman MJ , Nukajam WS, Somasundaram SG, Murphy B, J enkins AP, Crane RS \& Gregory GG (1999). Geography of intestinal permeability and absorption. Gut, 44: 483-489.

39. Faust EC (1935). The pathology of Strongyloides infection. Archives of Pathology, 19: 769-806.

40. Da Costa LR (1971). Small intestinal cell turnover in patients with parasitic infections. British Medical J ournal, 3: 281-283.

41. Garcia FT, Sessions JT, Strum WB, Schweistris $E$, Tripathy $K$, Bolaños $O$, Lotero H, Duque E, Ramelli D \& Mayoral LG (1977). Intestinal function and morphology in strongyloidiasis. American J ournal of Tropical Medicine and Hygiene, 26: 859-865.

42. Madsen J L, Scharff $O$, Rabøl A \& Krogsgaard OW (1996). Relationship between small intestinal transit rate and intestinal absorption of ${ }^{14} \mathrm{C}$-labelled mannitol and ${ }^{51} \mathrm{Cr}$-labelled ethylenediaminetetraacetic acid in healthy subjects. Scandinavian J ournal of Gastroenterology, 31: 254-259.

43. Laudanna AA, Polak M, Bettarello A \& Kieffer J (1973). Evidence of protein-losing enteropathy in strongyloidiasis. Revista do Instituto de Medicina Tropical de São Paulo, 15: 222-226. 